\title{
Anti-inflammatory properties of desipramine and fluoxetine
} Caroline Roumestan 1,2,4, Alain Michel ${ }^{2}$, Florence Bichon ${ }^{2}$, Karine Portet ${ }^{2}$, Maëlle Detoc ${ }^{1,5}$, Corinne Henriquet ${ }^{1,5}$, Dany Jaffuel ${ }^{3}$ and Marc Mathieu*1,6

\begin{abstract}
Address: ${ }^{1}$ Inserm, U454, Montpellier, F-34295, France, ${ }^{2}$ Laboratoire de Pharmacologie et Physiopathologie Expérimentales, Faculté de Pharmacie, Univ Montpellier, Montpellier, F-34090, France, ${ }^{3}$ Centre Médical Spécialisé de Pneumologie, 30 boulevard Kennedy, Béziers, F-34500, France, ${ }^{4}$ Present address : Laboratoires Macors, Auxerre, F-89000, France, ${ }^{5}$ Present address : Inserm, U826, Montpellier, F-34298, France and ${ }^{6}$ Present address : Inserm, U844, Montpellier, F-34091, France
\end{abstract}

Email: Caroline Roumestan - caroline.roumestan@macors.com; Alain Michel - amichel@univ-montp1.fr;

Florence Bichon - florence_laurent_bichon@yahoo.fr; Karine Portet - karine_portet@yahoo.fr; Maëlle Detoc - maelledetoc@hotmail.fr; Corinne Henriquet - chenriquet@valdorel.fnclcc.fr; Dany Jaffuel - dany.jaffuel@wanadoo.fr; Marc Mathieu* - mathieu@montp.inserm.fr

* Corresponding author

Published: 3 May 2007

Respiratory Research 2007, 8:35 doi:10.1 186/1465-9921-8-35

This article is available from: http://respiratory-research.com/content/8/I/35

This is an Open Access article distributed under the terms of the Creative Commons Attribution License (http://creativecommons.org/licenses/by/2.0), which permits unrestricted use, distribution, and reproduction in any medium, provided the original work is properly cited.

\begin{abstract}
Background: Antidepressants are heavily prescribed drugs and have been shown to affect inflammatory signals. We examined whether these have anti-inflammatory properties in animal models of septic shock and allergic asthma. We also analysed whether antidepressants act directly on peripheral cell types that participate in the inflammatory response in these diseases.

Methods: The antidepressants desipramine and fluoxetine were compared in vivo to the glucocorticoid prednisolone, an anti-inflammatory drug of reference. In a murine model of lipopolysaccharides (LPS)-induced septic shock, animals received the drugs either before or after injection of LPS. Circulating levels of tumour necrosis factor (TNF)- $\alpha$ and mortality rate were measured. In ovalbumin-sensitized rats, the effect of drug treatment on lung inflammation was assessed by counting leukocytes in bronchoalveolar lavages. Bronchial hyperreactivity was measured using barometric plethysmography. In vitro production of TNF- $\alpha$ and Regulated upon Activation, Normal T cell Expressed and presumably Secreted (RANTES) from activated monocytes and lung epithelial cells, respectively, was analysed by immunoassays. Reporter gene assays were used to measure the effect of antidepressants on the activity of nuclear factor- $\mathrm{\kappa B}$ and activator protein-I which are involved in the control of TNF- $\alpha$ and RANTES expression.
\end{abstract}

Results: In the septic shock model, all three drugs given preventively markedly decreased circulating levels of TNF- $\alpha$ and mortality $(50 \%$ mortality in fluoxetine treated group, $30 \%$ in desipramine and prednisolone treated groups versus $90 \%$ in controls). In the curative trial, antidepressants had no statistically significant effect, while prednisolone still decreased mortality ( $60 \%$ mortality versus $95 \%$ in controls). In ovalbumin-sensitized rats, the three drugs decreased lung inflammation, albeit to different degrees. Prednisolone and fluoxetine reduced the number of macrophages, lymphocytes, neutrophils and eosinophils, while desipramine diminished only the number of macrophages and lymphocytes. However, antidepressants as opposed to prednisolone did not attenuate bronchial hyperreactivity. In vitro, desipramine and fluoxetine dose-dependently inhibited the release of TNF- $\alpha$ from LPS-treated monocytes. In lung epithelial cells, these compounds decreased TNF- $\alpha$-induced RANTES expression as well as the activity of nuclear factor- $\mathrm{KB}$ and activator protein-I.

Conclusion: Desipramine and fluoxetine reduce the inflammatory reaction in two animal models of human diseases. These antidepressants act directly on relevant peripheral cell types to decrease expression of inflammatory mediators probably by affecting their gene transcription. Clinical implications of these observations are discussed. 


\section{Background}

It was hypothesized more than 30 years ago that depression involves a deficiency in monoamine neurotransmission. Immune activation may be causally related to these signaling disorders, as inflammatory cytokines have been shown to alter monoamine turnover, decrease activity of presynaptic serotoninergic neurons, and activate serotonin re-uptake from the synaptic cleft $[1,2]$. According to this hypothesis, therapeutic effects of antidepressants could be at least partly exerted by attenuating brain expression or action of inflammatory cytokines $[3,4]$. In this line, administration of the tricyclic antidepressant desipramine in rats has been shown to result in a virtual ablation of neuron-derived tumour necrosis factor (TNF)$\alpha[5,6]$. Intracerebroventricular microinfusion of TNF- $\alpha$ prevents the efficacy of desipramine while that of TNF- $\alpha$ antibody mimics the therapeutic effect of the antidepressant, providing further evidences that this cytokine plays a key role in the pathogenesis of depression [7].

Interestingly, antidepressants are also able to decrease peripheral inflammation. Chlomipramine, another tricyclic antidepressant, and fluoxetine, a specific inhibitor of serotonin reuptake, reduce oedema induced by the injection of yeast suspension in the rat hind paw $[8,9]$. Recently, preventive treatment with bupropion-amfebutamone, a noradrenalinedopamine reuptake inhibitor, was shown to reduce TNF- $\alpha$ release and mortality in a murine model of severe sepsis [10]. In these studies, the antiinflammatory effects of fluoxetine and bupropion involved, at least partly, a central action.

Depression is a common illness with a $17 \%$ lifetime prevalence in the general population [11]. Of note, depressive symptoms and disorders seem to be even more common in asthma patients $[12,13]$. Lifetime rates of depressive disorder of up to $41 \%$ have been reported in clinical samples of patients with asthma $[14,15]$. Thus, the aim of the present study was to determine the effect of desipramine and fluoxetine in two animal models of human inflammatory disorders, namely septic shock and allergic asthma. In the septic shock model, antidepressants were given either preventively or curatively. We report that desipramine and fluoxetine have therapeutic effects and counteract inflammation in these models. Our data further indicate that these antidepressants can directly act on relevant peripheral cell types to decrease expression of inflammatory cytokines. Finally, we show that desipramine and fluoxetine reduce the activity of the transcription factors nuclear factor (NF)- $\mathrm{kB}$ and activator protein (AP)-1, which have been shown to control expression of these cytokines $[16,17]$.

\section{Methods \\ Reagents}

12-O-tetradecanoyl-phorbol-13-acetate (TPA), lipopolysaccharides (LPS; Escherichia coli serotype 0111:B4), ovalbumin (OVA), aluminium hydroxide, metacholine, prednisolone and desipramine were purchased from Sigma. Fluoxetine was obtained from Tocris. Recombinant human TNF- $\alpha$ was purchased from BD Pharmingen. For in vivo studies, antidepressants and prednisolone were dissolved in saline. For in vitro studies, antidepressants were initially dissolved in absolute ethanol at $10^{-2}$ M. Dilutions with medium were freshly made from original stocks to a maximal concentration of $10^{-5} \mathrm{M}$ as in previous studies ([18] and references therein). No toxic effects of the drugs or solvents were observed at these dilutions as checked by vital staining with trypan blue and lactate dehydrogenase dosage in supernatants.

\section{Cell culture}

A549 human lung epithelial cells were maintained in Ham's F12/Dulbecco's modified Eagle's medium containing $10 \%$ heat-inactivated fotal calf serum, $100 \mathrm{U} / \mathrm{ml}$ penicillin, $100 \mathrm{mg} / \mathrm{ml}$ streptomycin and $2 \mathrm{mM}$ glutamine. Human monocytes were obtained by the following procedure. Buffy coats were collected from the blood of healthy donors. Blood mononuclear cells were isolated by density-gradient centrifugation through Ficoll-Hypaque (Pharmacia), suspended in RPMI 1640 medium with 10 $\%$ heat-inactivated foetal calf serum, and seeded in gelatincoated flasks. After incubation for $30 \mathrm{~min}$ at $37^{\circ} \mathrm{C}$, serial washes were performed to eliminate non-adherent cells and adherent monocytes were detached with $10 \mathrm{mM}$ EDTA, resuspended in Iscove's modified Eagle's medium containing $10 \%$ heat-inactivated foetal calf serum. The day before transfection and/or stimulation, cells were seeded in medium containing $5 \%$ charcoal/dextran treated foetal calf serum.

\section{Reporter plasmids}

The AP-1-luciferase gene construct -517/+63 Coll Luc consists of the luciferase gene driven by part of the collagenase promoter with its single AP-1 site (gift of Peter Herrlich, Institute of Genetics, Karlsruhe, Germany). The

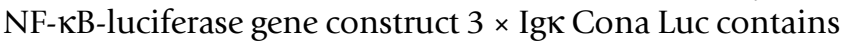
three tandem repeats of the NF- $\mathrm{\kappa B}$ response element from the immunoglobulin $\kappa$ chain linked to the conalbumin minimal promoter and the luciferase gene (gift of Alain Israël, Institut Pasteur, Paris, France). The pJ7-LacZ plasmid contains the SV40 early promoter linked to the $\beta$ galactosidase gene.

\section{RANTES and TNF- $\alpha$ immunoassays}

Concentrations of Regulated upon Activation, Normal T cell Expressed and presumably Secreted (RANTES) and TNF- $\alpha$ were determined using quantitative sandwich 
enzyme immuno-assays as described by the manufacturer (R\&D Systems).

\section{RANTES mRNA quantitation}

Total cellular RNA was isolated with RNA PLUS (Quantum Biotechnologies). Colorimetric RANTES mRNA quantitation was performed using a Quantikine mRNA kit (R\&D Systems).

\section{Transient transfection and reporter gene assays}

100000 cells per well were serum deprived overnight and transfected with $60 \mathrm{ng}$ of either $3 \times$ Igא Cona Luc or $-517 /$ +63 Coll Luc and 25 ng of pJ7-LacZ. These were then stimulated as indicated in the figure legends. Transfection, luciferase and $\beta$-galactosidase assays were performed as described previously [19]. Luciferase activity was divided by $\beta$-galactosidase activity to normalise values for variations in transfection efficiency.

\section{LPS-induced inflammation and endotoxic shock in mice}

The effect of antidepressants in septic shock was studied on 5-week-old BALB/c mice weighing 17-21 g (Elevage Janvier). To study their protective effect, animals received i.p. prednisolone, desipramine or fluoxetine at 5, 10 and $20 \mathrm{mg} / \mathrm{kg}$ or saline $30 \mathrm{~min}$ before injection of a lethal dose of LPS $(50 \mathrm{mg} / \mathrm{kg}$, i.p.). Ninety min after receiving LPS, blood was quickly collected from the trunk after decapitation. The serum was then isolated by centrifugation after clotting to determine the concentration of TNF- $\alpha$. Additional groups of mice receiving saline or the test drugs at $20 \mathrm{mg} / \mathrm{kg}$ before LPS treatment were observed for survival. To study the curative effect of antidepressants, animals received a lethal infusion of LPS and were treated with prednisolone $(20 \mathrm{mg} / \mathrm{kg}$, i.p), desipramine $(20 \mathrm{mg} / \mathrm{kg}$, i.p.), fluoxetine (20 mg/kg, i.p.) or saline $4,8,12,24$, and $30 \mathrm{~h}$ later. Mortality was evaluated daily.

\section{Measurement of bronchial responsiveness and inflammation in ovalbumin-sensitized rats}

Ten-week-old Brown Norway rats were sensitized to ovalbumin as follows: ovalbumin $(1 \mathrm{mg} / \mathrm{ml})$ was emulsified with aluminium hydroxide $(100 \mathrm{mg} / \mathrm{ml})$ in saline prior to i.p. injection of $1 \mathrm{ml}$ per rat at day 1, 2, 3 and 16. From day 22 to 29, prednisolone, desipramine, fluoxetine or saline were i.p. administered at $10 \mathrm{mg} / \mathrm{kg}$ to rats $30 \mathrm{~min}$ prior nebulisation with a $1 \%(\mathrm{w} / \mathrm{v})$ ovalbumin solution during $20 \mathrm{~min}$. Unsensitized controls received i.p. injections of aluminium hydroxide alone. These were then nebulised with saline from day 22 to 28 and challenged with ovalbumin on day 29. Bronchial responsiveness to metacholine $(10 \mathrm{mg} / \mathrm{ml}$ nebulised during $2 \mathrm{~min})$ was analysed by barometric plethysmography (Emka Technologies) on conscious unrestrained animals $24 \mathrm{~h}$ after the last ovalbumin nebulisation. Enhanced pause (Penh), reflecting the resistance to air flow, and hence airway obstruc- tion, was measured. Rats were then anaesthetized with pentobarbital and exsanguinated by catheterization of the abdominal aorta to avoid contamination of bronchoalveolar lavages with red cells. The trachea was stripped and rinsed in situ with PBS. Total number of cells in bronchoalveolar lavages was immediately determined by counting on Malassez chamber. The different cell types were distinguished and counted after cytocentrifugation, fixation and May Grünwald Giemsa staining. These experimentations have been carried out in accordance with the Declaration of Helsinki and with the Guide for the Care and Use of Laboratory Animals as adopted and promulgated by the US National Institutes of Health. Our laboratory practice was approved by the "Comité Régional d'Ethique pour l'Expérimentation Animale du Languedoc-Roussillon ».

\section{Statistical analysis}

Data obtained in vitro are presented as mean \pm SE of at least three independent experiments performed in duplicates. Analysis of in vivo experiments was done on 6 to 31 animals per treatment group. Data were analysed using the Instat software (GraphPad Software, San Francisco, CA). Statistical significance was set up at $\mathrm{p}<0.05$.

\section{Results \\ Pretreatment with desipramine and fluoxetine prevent LPS-induced systemic inflammation and mortality in mice} The protective effect of desipramine and fluoxetine was tested in a murine model of septic shock, in which endotoxemia and systemic inflammation is triggered by LPS injection. Production of TNF- $\alpha$ is one of the earliest events induced by LPS. Indeed, upon LPS treatment, concentration of TNF- $\alpha$ in the serum reached a peak after $90 \mathrm{~min}$ and was back to basal level after $3 \mathrm{~h}$ (Fig. 1A and data not shown). Therefore, mice were pretreated with the test compound or saline 30 min before injection of LPS and TNF- $\alpha$ concentration was measured 90 min afterwards. Significant inhibition of TNF- $\alpha$ production occurred with either drug at $5 \mathrm{mg} / \mathrm{kg}$. This dose corresponds to the recommended daily dosage of desipramine in humans. Because the inhibitory effect of prednisolone, desipramine and fluoxetine was stronger at 10 or $20 \mathrm{mg} /$ $\mathrm{kg}$, these doses were used in following experiments (Fig. $1 \mathrm{~B})$. We next analysed the survival of mice injected with LPS and pretreated with $20 \mathrm{mg} / \mathrm{kg}$ of prednisolone, desipramine or fluoxetine. These compounds notably increased survival. The proportion of living mice rose from $10 \%$ in the control group to $50 \%$ in the fluoxetine group, and to $70 \%$ in the prednisolone and desipramine groups (Fig. 2).

\section{Effect of curative treatment with desipramine and fluoxetine on LPS-induced mortality in mice}

Because severe sepsis is an acute inflammatory syndrome, specific treatment in the clinic is initiated after symptoms 


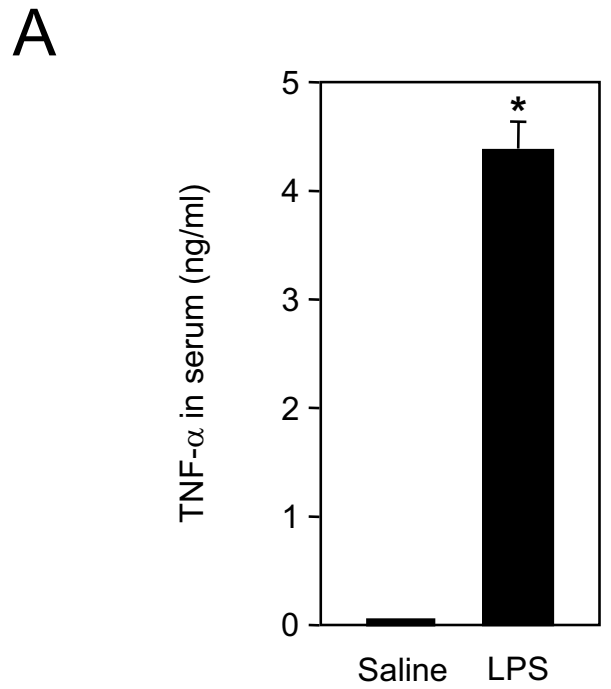

B

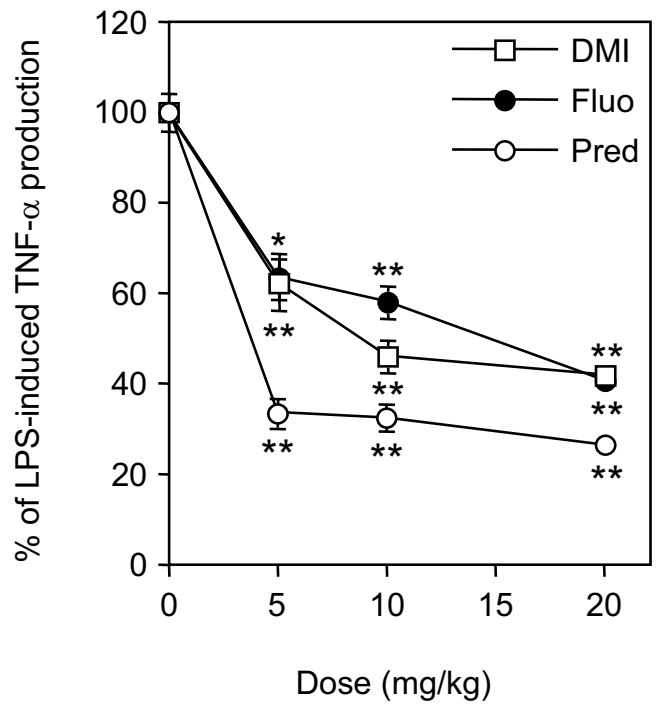

Figure I

Desipramine and fluoxetine inhibit release of TNF- $\alpha$ in serum of LPS-treated mice. A, Mice ( $n=12$ per group) were injected with saline or LPS $(50 \mathrm{mg} / \mathrm{kg}$, i.p.). After $90 \mathrm{~min}$, blood was collected and serum concentration of TNF- $\alpha$ was measured. Concentration was $38 \pm 12 \mathrm{pg} / \mathrm{ml}$ in saline and $4364 \pm 265 \mathrm{pg} / \mathrm{ml}$ in LPStreated mice. $*_{p}<0.0001$ versus saline, by Welch $t$ test. $B$, Mice $(n=$ 6-12 per group) were i.p. injected with saline or the indicated doses of desipramine, fluoxetine or prednisolone $30 \mathrm{~min}$ before administration of LPS. Blood was collected 90 min after LPS treatment, and serum concentration of TNF- $\alpha$ was measured. Data are shown as the percentage of LPS-induced TNF- $\alpha$ release. $*_{p}<0.05$ and $* * p<0.001$ versus LPS alone, by ANOVA with Bonferroni post-test.

have been declared. To mimic such curative treatment in mice, repeated injections of antidepressants or prednisolone were performed, starting $4 \mathrm{~h}$ after administration of LPS, a time at which the first signs of sepsis such as diarrhoea, hypoactivity, piloerection, and shivering are apparent. Prednisolone significantly increased the survival of mice (40\% survival versus $5 \%$ in the control group) (Fig. 3 ). Fluoxetine had no curative effect while desipramine delayed time of death by few hours (Fig. 3). However, this latter effect was not statistically significant.

\section{Desipramine and fluoxetine inhibit release of TNF- $\alpha$ from freshly isolated human monocytes}

Monocytes are the main source of TNF- $\alpha$ produced in the blood stream during septic shock. Therefore, we next tested whether desipramine and fluoxetine could act directly on monocytes to inhibit LPS-induced TNF- $\alpha$ release. After LPS treatment of human monocytes in primary cultures, concentration of TNF- $\alpha$ in supernatants raised from $226 \pm 16 \mathrm{pg} / \mathrm{ml}$ to $2848 \pm 309 \mathrm{pg} / \mathrm{ml}$ (Fig. 4A). As shown in Fig. 4B, desipramine and fluoxetine dosedependently inhibited TNF- $\alpha$ release.

\section{Desipramine and fluoxetine reduce bronchial inflammation but not hyper responsiveness in ovalbumin- sensitized rats}

The anti-inflammatory effects of antidepressants were also analysed in an animal model of allergic asthma. Brown Norway rats were sensitized to ovalbumin to trigger bronchial hyperresponsiveness and airway inflammation. The increase in bronchial responsiveness to metacholine observed in sensitized rats was significantly reduced by prednisolone but not by desipramine or fluoxetine (Fig. 5). Bronchoalveolar lavages of sensitized rats contained an increased number of total inflammatory cells, which was markedly inhibited by the three drugs (Fig. 6). Analysis of leukocytes sub-populations revealed that prednisolone and fluoxetine reduced the number of macrophages (by $60 \%$ and 51\%, respectively), lymphocytes (by $70 \%$ and 33\%, respectively), neutrophils (by $72 \%$ and $38 \%$, respectively) and eosinophils (by $97 \%$ and $60 \%$, respectively), while desipramine diminished only the number of macrophages (by 52\%) and lymphocytes (by 21\%) (Fig. 7).

\section{Desipramine and fluoxetine inhibit expression of RANTES in lung $A 549$ epithelial cells}

Accumulation of inflammatory cells in bronchoalveolar lavages may result, at least in part, from an effect on lung epithelial cells which have the capacity to produce chemokines. Thus, we examined the effect of desipramine and fluoxetine on RANTES production in A549 lung epithelial cells. After TNF- $\alpha$ treatment, concentration of RANTES in cell culture supernatants raised from $7 \pm 5 \mathrm{pg} / \mathrm{ml}$ to 2659 $\pm 227 \mathrm{pg} / \mathrm{ml}$ (Fig. 8A). Antidepressants dose dependently inhibited TNF- $\alpha$-induced RANTES release. A maximal inhibition of $50 \%$ was obtained at $10^{-5} \mathrm{M}$ (Fig. 8B). TNF$\alpha$-induced RANTES transcripts accumulation was also 


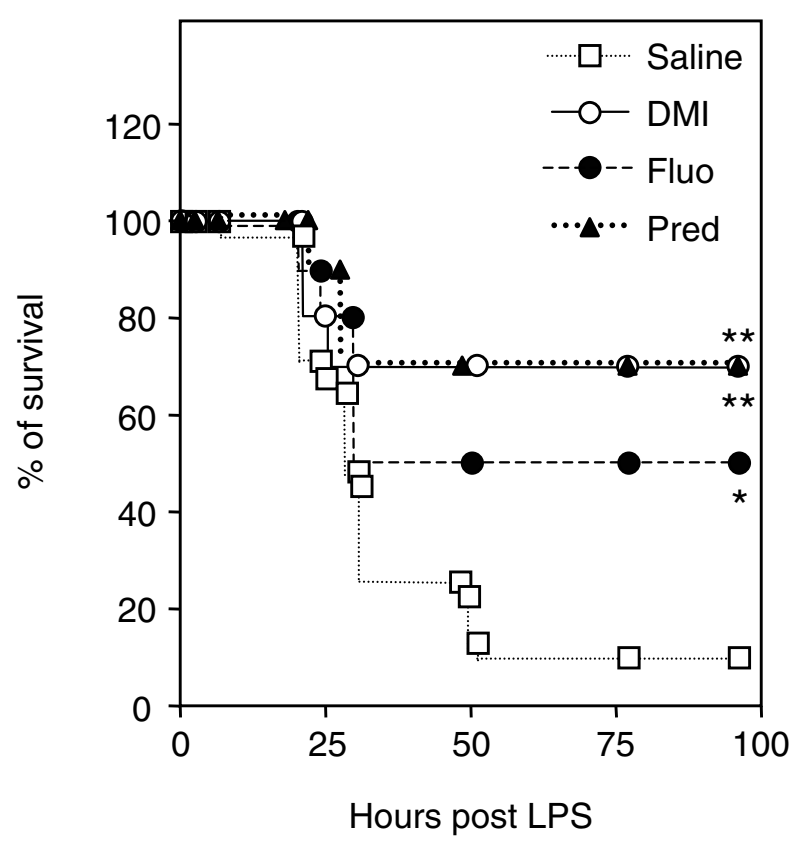

Figure 2

Pretreatment with desipramine and fluoxetine prevents LPS-induced mortality. Mice $(n=|0-3|$ per group) were injected with saline, desipramine (DMI, $20 \mathrm{mg} /$ $\mathrm{kg}$, i.p.), fluoxetine (Fluo, $20 \mathrm{mg} / \mathrm{kg}$, i.p.) or prednisolone (Pred, $20 \mathrm{mg} / \mathrm{kg}$, i.p.) as indicated $30 \mathrm{~min}$ before administration of LPS (50 mg/kg, i.p.). Kaplan-Meier survival curves represent the percentage of surviving individuals in each groups. Survival is shown over a $96 \mathrm{~h}$ period (no additional death occurred after $96 \mathrm{~h}$ ). $*_{p}=0.0129$ and $*_{p} *_{p}=0.0005$ versus saline, by Fisher's exact test.

decreased by approximately 50\% after treatment by either antidepressant (Fig. 8C).

\section{Desipramine and fluoxetine repress NF- $K B$ and AP-I activities}

Because NF- $\mathrm{B}$ and AP-1 play a crucial role in the expression and action of inflammatory mediators such as TNF- $\alpha$ and RANTES, activity of these transcription factors was measured in A549 cells treated by desipramine or fluoxetine. Both antidepressants significantly repressed TNF- $\alpha$ induced NF- $\mathrm{BB}$ activity by about 40\% (Fig. 9A). Desipramine and fluoxetine decreased TPA-induced AP-1 activity by $30 \%$ and $25 \%$, respectively (Fig. 9B).

\section{Discussion}

\section{Central versus peripheral action}

In the present study, desipramine and fluoxetine are shown to affect the capacity of monocytes and lung epithelial cells to produce inflammatory cytokines in vitro. This observation favours a direct peripheral anti-inflammatory action of antidepressants. However, fluoxetine but not the desipramine-related compound chlomipramine

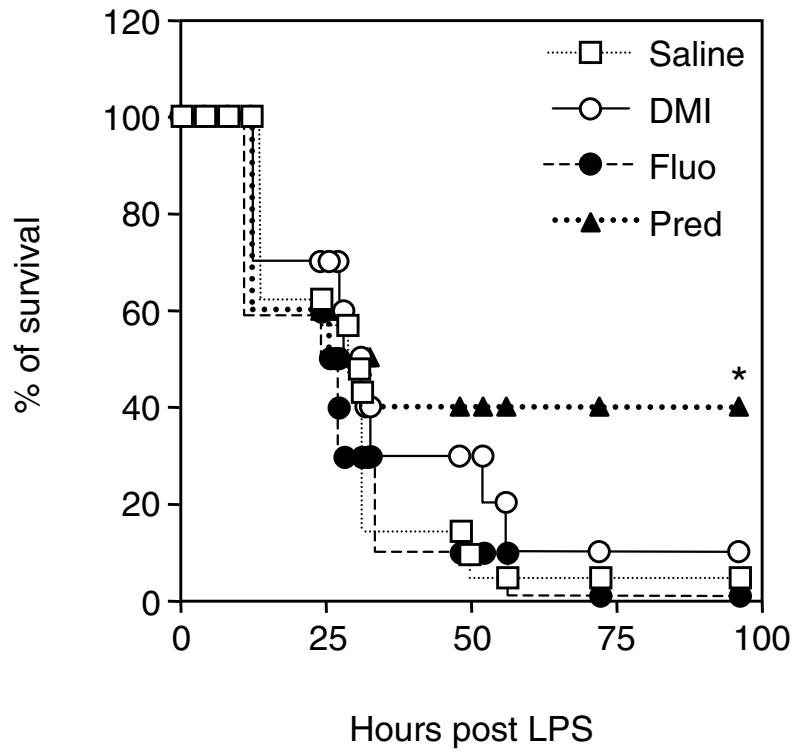

Figure 3

Effect of a curative treatment with desipramine or fluoxetine on LPS-induced mortality. Mice $(n=10-2 \mid$ per group) were treated with prednisolone (Pred, $20 \mathrm{mg} / \mathrm{kg}$, i.p), desipramine (DMI, $20 \mathrm{mg} / \mathrm{kg}$, i.p.), fluoxetine (Fluo, 20 $\mathrm{mg} / \mathrm{kg}$, i.p.) or saline $4,8,12,24$, and $30 \mathrm{~h}$ after administration of LPS (50 mg/kg, i.p.) as indicated. Kaplan-Meier survival curves represent the percentage of surviving individuals in each groups. Mortality was evaluated daily (no additional death occurred after $96 \mathrm{~h}$ ). ${ }^{*} \mathrm{p}=0.0274$ versus saline, by Fisher's exact test.

has been shown to trigger anti-inflammatory effects through the potentiation of serotoninergic transmission ending up in activation of the pituitary-adrenocortical axis $[8,9]$. Further evidence for a central mechanism was provided for bupropion-amfebutamone in a murine model of severe sepsis. In this study, $\beta$-adrenergic and dopaminergic receptor antagonists partially prevented bupropion from reducing mortality rate [10]. To determine the relative contribution of central and peripheral action in the anti-inflammatory effects, it would be interesting to modify antidepressant molecules so that they do not cross the blood-brain barrier. If active, such molecules could become prototypes for new anti-inflammatory drugs.

\section{Molecular targets of antidepressants}

The few previous reports investigating the effects of antidepressants on AP-1 and NF- $\mathrm{KB}$ were performed with brain tissues or a neuronal cell line. Antidepressants were found to regulate either positively or negatively DNA binding activity of these transcription factors, depending on the drug's chemical class, the brain region, and on whether administration was acute or chronic [20-22]. We report that desipramine and fluoxetine repress NF- $\mathrm{B}$ and AP-1 activities in a lung epithelial cell line. This may 
A

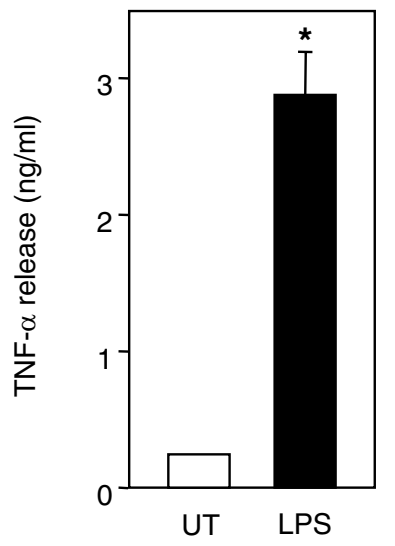

B

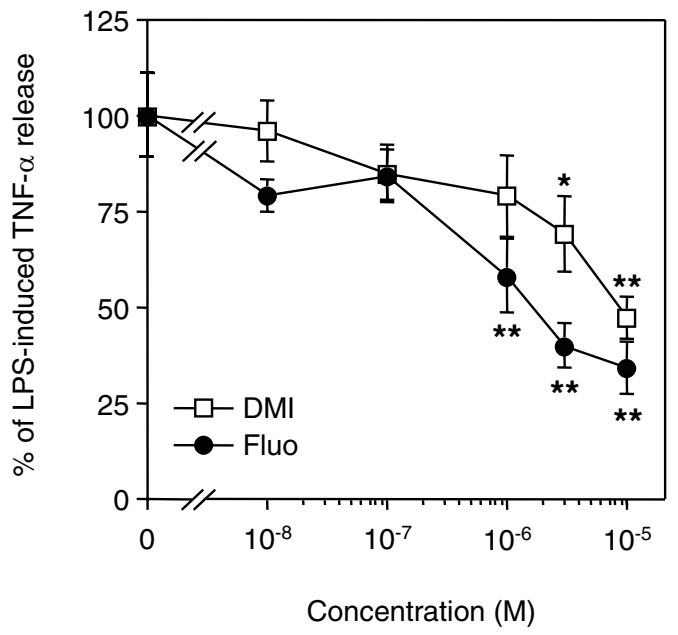

Figure 4

Desipramine and fluoxetine inhibit release of TNF- $\alpha$ from cultured monocytes. A, Purified human monocytes were seeded at 100000 cells per well and were left untreated (UT) or stimulated for $20 \mathrm{~h}$ with $100 \mathrm{ng} / \mathrm{ml}$ of LPS. Concentration of TNF$\alpha$ in supernatants was then measured. ${ }_{p} p<0.0001$ versus untreated, by Welch $t$ test. B, Cells were treated for $20 \mathrm{~h}$ with $100 \mathrm{ng} / \mathrm{ml}$ of LPS in the presence of increasing concentrations of desipramine (DMI) or fluoxetine (Fluo). Data are shown as the percentage of LPS-induced TNF- $\alpha$ release. ${ }^{*} \mathrm{p}<0.05$ and ${ }^{* *} \mathrm{p}<$ 0.001 versus LPS alone, by ANOVA with Bonferroni post-test.

account for their anti-inflammatory effects in the animal model of asthma as observed here. Indeed, AP-1 and NF$\kappa \mathrm{B}$ have been involved in the pathogenesis of various chronic inflammatory diseases, including asthma and allergy $[23,24]$. In addition, NF- $\kappa \mathrm{B}$ plays a key role in the mortality of sepsis [25]. Thus, repression of NF- $\kappa B$ activity by antidepressants may also explain their protective effect in the model of septic shock. Concentrations of 1 to 10 $\mu \mathrm{M}$ were required to down-regulate AP- 1 and NF- $\kappa B$ activ-

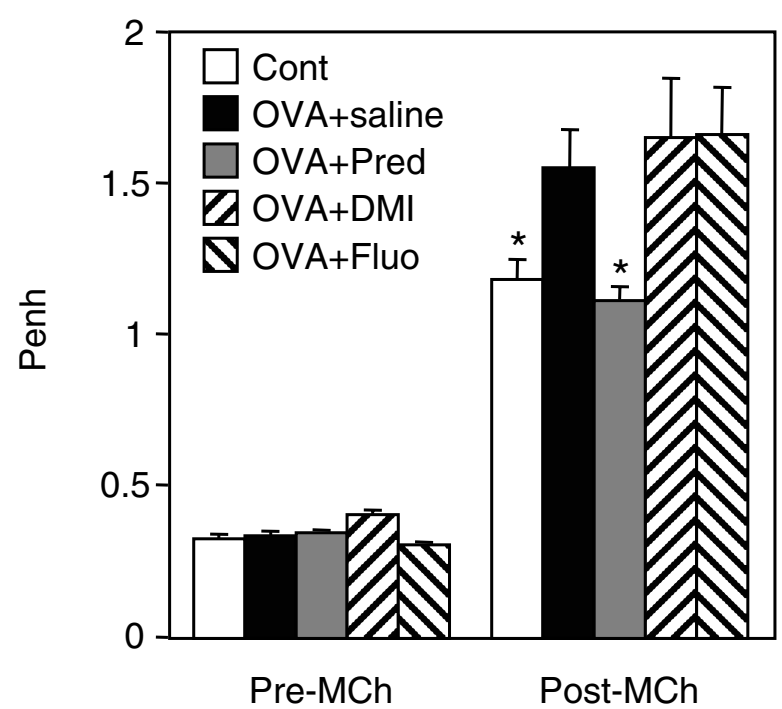

Figure 5

Desipramine and fluoxetine do not reduce bronchial hyper responsiveness in sensitized rats. Unsensitized control rats (Cont) were nebulised with ovalbumin. Ovalbumin-sensitized rats were treated with saline (OVA+saline), prednisolone (OVA+Pred), desipramine (OVA+DMI) or fluoxetine (OVA+Fluo) at $10 \mathrm{mg} / \mathrm{kg}$ prior to nebulisation with ovalbumin. Rats ( $n=6-7$ per group) were then challenged with metacholine $24 \mathrm{~h}$ after ovalbumin nebulisation. Enhanced pause (Penh), which reflects airway obstruction, was measured by barometric plethysmography before (PreMch) and after (Post-Mch) the challenge. ${ }^{*} p<0.05$ versus OVA+saline, by Student $t$ test.

ities and expression of inflammatory cytokines. Such concentrations of antidepressants are reached in the plasma $[26,27]$, but are 10 to 1000 times higher than the dissociation constant of antidepressants for monoamine transporters and receptors. Moreover, monoamine transporters and receptors recognized by desipramine and fluoxetine are not expressed in A549 cells as checked using oligonucleotide microarrays (data not shown). Hence, antidepressants should exert their anti-inflammatory effects through lower affinity receptors or effectors that remain to be identified. Interestingly, fluoxetine at 5 to $15 \mu \mathrm{M}$ was shown to interfere with the activity of extrusion pumps [28]. Similarly, desipramine at $10 \mu \mathrm{M}$ was found to reduce P-glycoprotein-like activity in vitro, thereby enhancing glucocorticoid action [18]. As opposed to this latter study, in our in vitro assays, antidepressants produced antiinflammatory effects in the complete absence of glucocorticoid. Moreover, A549 cells do not express P-glycoprotein [29]. The effects of antidepressants in these cells are thus not mediated through modulation of P-glycoprotein. 


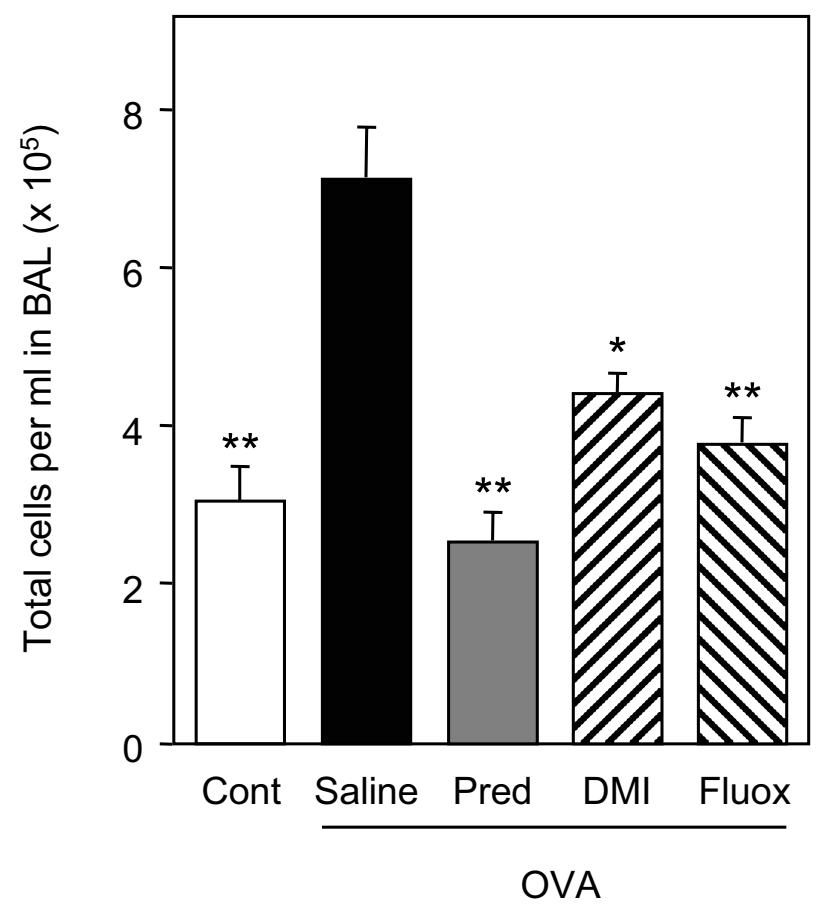

Figure 6

Desipramine and fluoxetine inhibit influx of inflammatory cells in bronchoalveolar lavages of sensitized rats. Ovalbumin-sensitized rats (OVA) treated with saline, prednisolone (Pred, $10 \mathrm{mg} / \mathrm{kg}$ ), desipramine (DMI, $10 \mathrm{mg} / \mathrm{kg}$ ) or fluoxetine (Fluo, $10 \mathrm{mg} / \mathrm{kg}$ ) and control rats (Cont) $(\mathrm{n}=$ 6-7 per group) were challenged with metacholine. Total number of inflammatory cells in bronchoalveolar lavages was then determined. ${ }^{*} p<0.01$ and $* * p<0.001$ versus ovalbumin-sensitized rats treated with saline, by Student $t$ test.

Nevertheless, inhibition of drug efflux transporters in vivo should increase concentration of endogenous glucocorticoids some in target cells and may account, at least partly, for the anti-inflammatory properties of antidepressants.

\section{Therapeutic effect of desipramine and fluoxetine in models of inflammatory diseases}

The data presented herein demonstrate that desipramine and fluoxetine have significant antiinflammatory properties in animal models of allergic asthma and septic shock. Preventive treatment with desipramine and fluoxetine markedly reduced TNF- $\alpha$ production and mortality in the LPS-induced septic shock model. Desipramine provided the same protection against mortality as the glucocorticoid prednisolone. However, it was less potent than prednisolone in reducing TNF- $\alpha$ production. It is not surprising that the inhibitory effect on TNF- $\alpha$ production is not strictly correlated with survival rate since TNF- $\alpha$ is not the sole mediator of lethality in severe sepsis [30]. Recently, another antidepressant, bupropion-amfebuta- mone, was also shown to have a preventive therapeutic effect in a murine model of severe sepsis [10]. In the same model, we further show that antidepressants administered curatively do not reduce final mortality rate, although desipramine seem to delay time of death by few hours.

In the model of allergic asthma, antidepressants reduced lung inflammation but not bronchial hyper responsiveness, whereas prednisolone was active on both aspects of the pathology. Moreover, both antidepressants were not as efficient as prednisolone in inhibiting inflammatory cell counts. Thus, desipramine and fluoxetine exert weaker or more restricted anti-inflammatory effects compared to those of a glucocorticoid. Moreover, differences were noted between the anti-inflammatory potencies of desipramine and fluoxetine. Desipramine did not reduce lung infiltration of neutrophils and eosinophils as opposed to fluoxetine. Yet, in cultured lung epithelial cells, both antidepressants inhibited with similar efficacy the production of RANTES, a known chemotactic for eosinophils. Possibly, expression of other eosinophils chemoattractants is affected by fluoxetine but not by desipramine in the ovalbumin-sensitized rat model. Our observation made in this model is also in apparent contradiction with data obtained by others showing an inhibition of neutrophils migration by tricyclic antidepressants but not by fluoxetine [31]. However, in this latter study, the migration experiments were performed with neutrophils in vitro. In vivo, antidepressants have a different effect probably because they act on various additional cell types such as T cells, macrophages, endothelial and epithelial cells that affect the migration process.

\section{Conclusion}

The observation that antidepressants have anti-inflammatory properties might have important clinical implications since these drugs are heavily prescribed worldwide and chronic treatment often lasts several months. In France alone, over 11 millions prescriptions for antidepressants were made during year 2000 [32]. Moreover, there is a high prevalence of depression in patients with asthma or other chronic inflammatory diseases $[12,13,33]$. Thus, the anti-inflammatory effects of antidepressants should be considered especially in depressive patients with inflammatory co-morbidity. In this regard, tianeptine and citalopram, two antidepressants with yet opposite action on serotonin re-uptake, were shown to provide clinical benefit in asthma. In asthmatic children, tianeptine reduces asthma symptoms and increases pulmonary function [34], while in patients with asthma and major depressive disorder, citalopram decreases systemic glucocorticoid use, an important measure of severe asthma exacerbations [35]. Tianeptine decreases free serotonin plasma levels which are high in symptomatic patients with asthma, and seems thus to act as a bron- 
A

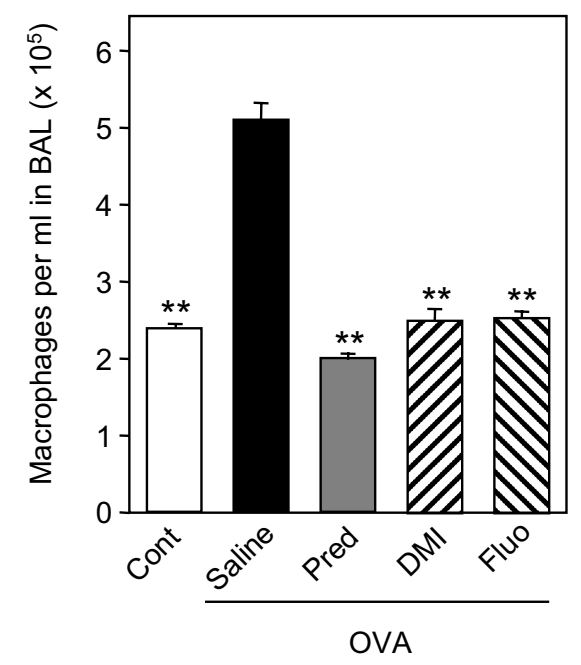

C

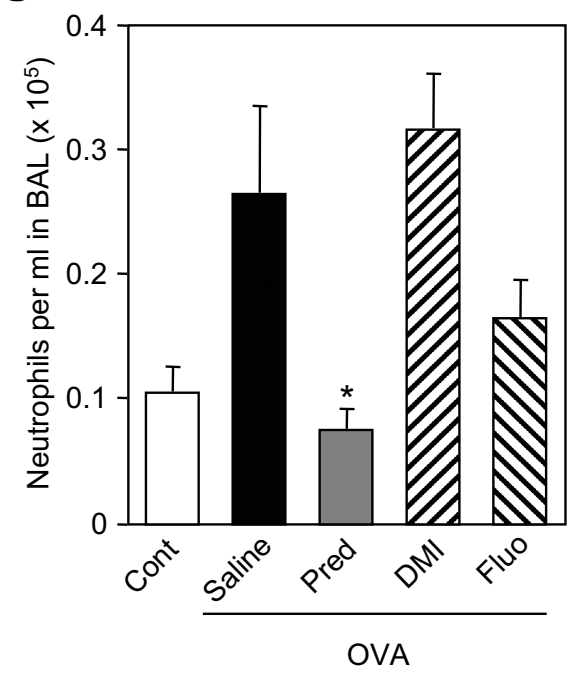

$\mathrm{B}$

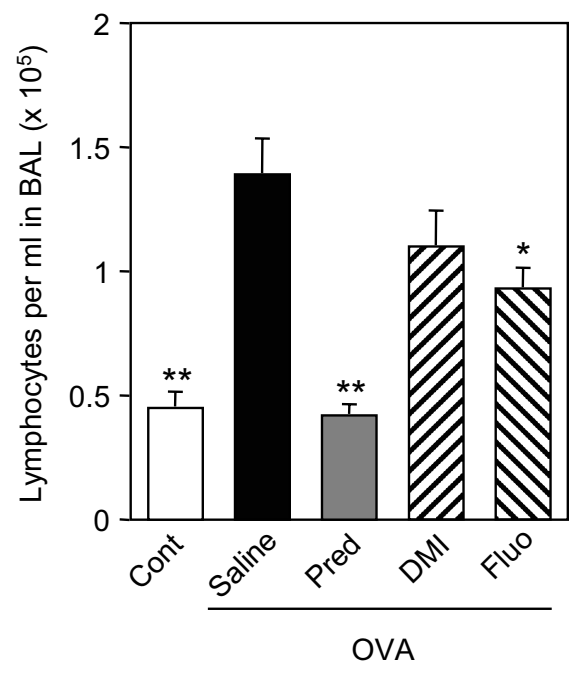

$\mathrm{D}$

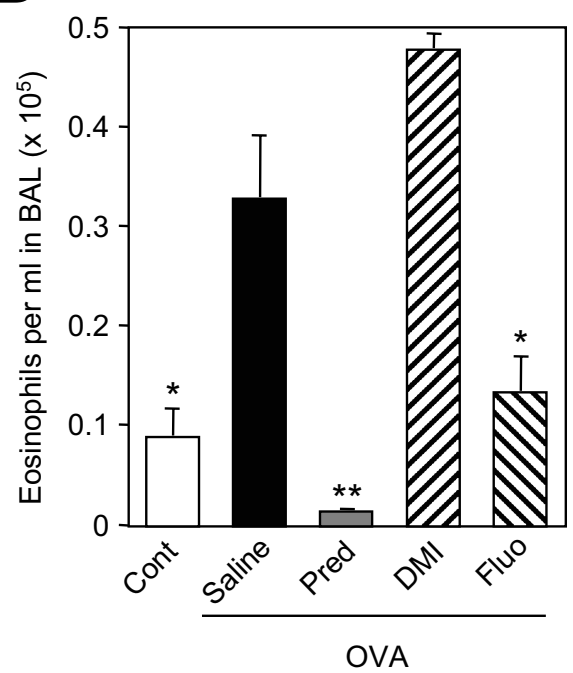

Figure 7

Effects of desipramine and fluoxetine on leukocyte sub-populations in bronchoalveolar lavages of sensitized rats. Ovalbumin-sensitized rats (OVA) treated with saline, prednisolone (Pred, $10 \mathrm{mg} / \mathrm{kg}$ ), desipramine (DMl, $10 \mathrm{mg} / \mathrm{kg}$ ) or fluoxetine (Fluo, $10 \mathrm{mg} / \mathrm{kg}$ ) and control rats (Cont) ( $\mathrm{n}=6-7$ per group) were challenged with metacholine. Cells in bronchoalveolar lavages were spun down on cytoslides, fixated and stained. Macrophages (panel A), lymphocytes (panel B), neutrophils (panel C) and eosinophils (panel D) were then counted under a microscope. A minimum of 200 cells was counted for each bronchoalveolar lavage. ${ }^{*} p<0.05$ and $*_{p} *<0.001$ versus ovalbumin-sensitized rats treated with saline, by Student $t$ test.

chodilator. Obviously, another mechanism underlies the anti-inflammatory properties of desipramine and fluoxetine since these drugs do not reduce bronchial hyperresponsiveness as shown herein. To ascertain the significance of their anti-inflammatory effects in humans, further clinical trials with antidepressants are required as well as retrospective epidemiological studies assessing the prevalence of inflammatory disorders, including septic shock, in antidepressant-treated subjects.

\section{Abbreviations}

$\mathrm{I} \kappa \mathrm{B}$, inhibitor of nuclear factor- $\kappa \mathrm{B}$; IKK, inhibitor of nuclear factor- $\kappa B$ kinase; i.p., intraperitoneally; LPS, lipopolysaccharides; NF- $\kappa \mathrm{B}$, nuclear factor- $\kappa \mathrm{B}$; OVA, oval- 
A

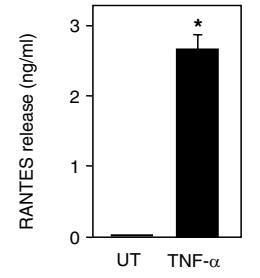

B

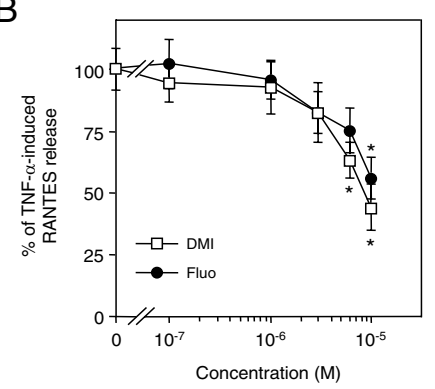

C

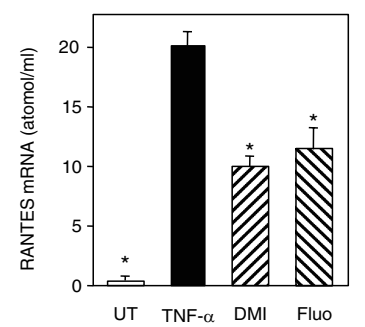

Figure 8

Desipramine and fluoxetine inhibit RANTES expression. $A, A 549$ cells were left untreated (UT) or stimulated for $20 \mathrm{~h}$ with TNF- $\alpha$ at $10 \mathrm{ng} / \mathrm{ml}$. Concentration of RANTES in supernatants was then measured. ${ }^{*} p<0.000$ I versus untreated, by Welch t test. B, A549 cells were stimulated for $20 \mathrm{~h}$ with $10 \mathrm{ng} / \mathrm{ml}$ of TNF- $\alpha$ in the presence of increasing concentrations of desipramine or fluoxetine. Data are shown as the percentage of TNF- $\alpha$-induced RANTES release. ${ }^{*} p<$ 0.05 versus TNF- $\alpha$ alone, by ANOVA with Bonferroni posttest. C, A549 cells were either left untreated (UT) or pretreated or not for I $\mathrm{h}$ with desipramine (DMI) or fluoxetine (Fluo) at $10^{-5} \mathrm{M}$ and further stimulated for $4 \mathrm{~h}$ with TNF- $\alpha$ at $10 \mathrm{ng} / \mathrm{ml}$. The amount of RANTES mRNA was quantified by a colorimetric assay. ${ }^{*} p<0.05$ versus TNF- $\alpha$ alone, by Student t test.

bumin; PBMC, peripheral blood mononuclear cells; Penh, enhanced pause; RANTES, Regulated upon Activation, Normal T cell Expressed and presumably Secreted; TNF- $\alpha$, tumour necrosis factor- $\alpha$; TPA, 12-O-tetradecanoyl-phorbol-13-acetate.
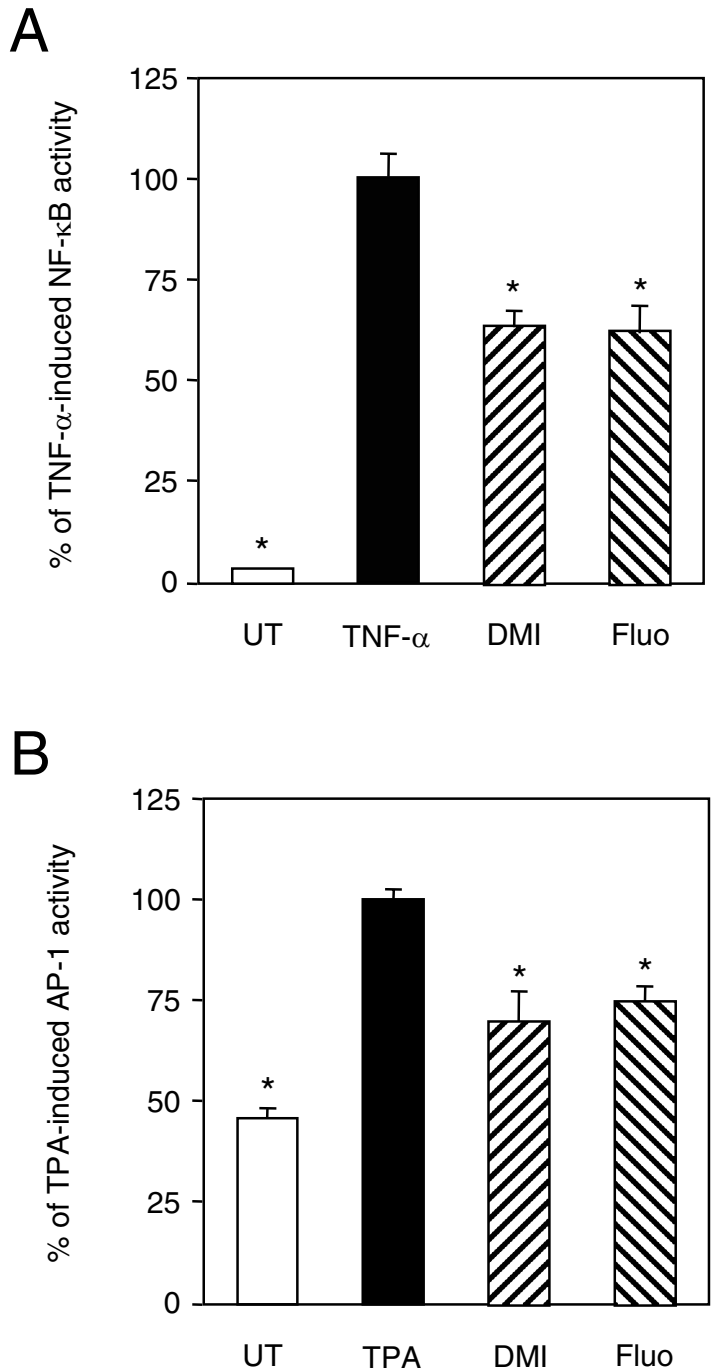

Figure 9

Desipramine and fluoxetine repress NF- $K B$ and AP- I activities. A, A549 cells were transfected with a NF- $\kappa B$ luciferase gene construct and pJ7-LacZ. After transfection, cells were either left untreated (UT) or pretreated or not for I $h$ with desipramine (DMI, $10^{-5} \mathrm{M}$ ) or fluoxetine (Fluo, $10^{-5} \mathrm{M}$ ), and further stimulated for $4 \mathrm{~h}$ with TNF- $\alpha(\mathrm{I} 0 \mathrm{ng} / \mathrm{ml})$. NF- $\mathrm{KB}$ activity was normalised and that induced by TNF- $\alpha$ alone (47 \pm 8 fold induction) was given the nominal value of $100 \%$. Data are shown as the percentage of activity relative to this nominal value. ${ }^{*} p<0.00$ I versus TNF- $\alpha$ alone, by Welch $t$ test. B, A549 cells were transfected with an AP-I luciferase gene construct and pJ7-LacZ. After transfection, cells were either left untreated (UT) or pretreated or not for I h as in $\mathrm{A}$, and further stimulated for $4 \mathrm{~h}$ with TPA $(10 \mathrm{ng} / \mathrm{ml})$. AP-I activity was normalised and that induced by TPA alone $(2.3 \pm$ 0.1 fold induction) was given the nominal value of $100 \%$. Data are shown as the percentage of activity relative to this nominal value. ${ }^{*} p<0.01$ versus TPA alone, by Welch $t$ test. 


\section{Competing interests}

The author(s) declare that they have no competing interests.

\section{Authors' contributions}

CR conceived of the study, acquired and analysed most of the data. AM participated in the conception of the in vivo experiments. $\mathrm{AM}, \mathrm{FB}, \mathrm{KP}$ and $\mathrm{MD}$ helped to carry out the in vivo assays. $\mathrm{CH}$ helped to carry out the in vitro assays. DJ participated in the study design and revised the manuscript critically. MM coordinated the study, participated in the acquisition, analysis and interpretation of the data and drafted the manuscript. All authors read and approved the final manuscript.

\section{Acknowledgements}

We are grateful to Peter Herrlich and Alain Israël for the kind gift of reagents. We thank Luc Gillet for animal care.

\section{References}

I. Leonard BE: The immune system, depression and the action of antidepressants. Prog Neuropsychopharmacol Biol Psychiatry 200I, 25(4):767-780.

2. Schiepers OJ, Wichers MC, Maes M: Cytokines and major depression. Prog Neuropsychopharmacol Biol Psychiatry 2005, 29(2):20I-2I7.

3. Licinio J, Wong ML: The role of inflammatory mediators in the biology of major depression: central nervous system cytokines modulate the biological substrate of depressive symptoms, regulate stress-responsive systems, and contribute to neurotoxicity and neuroprotection. Mol Psychiatry 1999 , 4(4):317-327.

4. Castanon N, Leonard BE, Neveu PJ, Yirmiya R: Effects of antidepressants on cytokine production and actions. Brain Behav Immun 2002, I6(5):569-574.

5. Ignatowski TA, Noble BK, Wright JR, Gorfien JL, Heffner RR, Spengler RN: Neuronal-associated tumor necrosis factor (TNF[alpha]): its role in noradrenergic functioning and modification of its expression following antidepressant drug administration. Journal of Neuroimmunology 1997, 79(I):84-90.

6. Reynolds JL, Ignatowski TA, Sud R, Spengler RN: An antidepressant mechanism of desipramine is to decrease tumor necrosis factor-alpha production culminating in increases in noradrenergic neurotransmission. Neuroscience 2005, |33(2):5|9-53|.

7. Reynolds JL, Ignatowski TA, Sud R, Spengler RN: Brain-derived tumor necrosis factor-alpha and its involvement in noradrenergic neuron functioning involved in the mechanism of action of an antidepressant. J Pharmacol Exp Ther 2004, 310(3): $1216-1225$.

8. Bianchi M, Sacerdote $P$, Panerai AE: Chlomipramine differently affects inflammatory edema and pain in the rat. Pharmacol Biochem Behav 1994, 48(4): 1037-1040.

9. Bianchi M, Sacerdote P, Panerai $A E$ : Fluoxetine reduces inflammatory edema in the rat: involvement of the pituitary-adrenal axis. Eur J Pharmacol 1994, 263(I - 2):8I-84.

10. Brustolim D, Ribeiro-dos-Santos R, Kast RE, Altschuler EL, Soares $M B: A$ new chapter opens in anti-inflammatory treatments: the antidepressant bupropion lowers production of tumor necrosis factor-alpha and interferon-gamma in mice. Int Immunopharmacol 2006, 6(6):903-907.

II. Blazer DG, Kessler RC, McGonagle KA, Swartz MS: The prevalence and distribution of major depression in a national community sample: the National Comorbidity Survey. Am J Psychiatry 1994, I 5 I (7):979-986.

12. Hurwitz EL, Morgenstern H: Cross-sectional associations of asthma, hay fever, and other allergies with major depression and low-back pain among adults aged $20-39$ years in the United States. Am J Epidemiol 1999, I 50(10): I 107-III6.
13. Zielinski TA, Brown ES, Nejtek VA, Khan DA, Moore JJ, Rush AJ: Depression in Asthma: Prevalence and Clinical Implications. Prim Care Companion J Clin Psychiatry 2000, 2(5): I53-158.

14. Nejtek VA, Brown ES, Khan DA, Moore JJ, Van Wagner J, Perantie DC: Prevalence of mood disorders and relationship to asthma severity in patients at an inner-city asthma clinic. Ann Allergy Asthma Immunol 200I, 87(2): 129-I33.

15. Brown ES, Khan DA, Mahadi S: Psychiatric diagnoses in inner city outpatients with moderate to severe asthma. Int J Psychiatry Med 2000, 30(4):319-327.

16. Siebenlist U, Franzoso G, Brown K: Structure, regulation and function of NF-kB. Annu Rev Cell Biol 1994, 10:405-455.

17. Moriuchi H, Moriuchi M, Fauci AS: Nuclear factor-kappa B potently up-regulates the promoter activity of RANTES, a chemokine that blocks HIV infection. J Immunol 1997, | 58(7):3483-349|.

18. Pariante CM, Makoff A, Lovestone S, Feroli S, Heyden A, Miller AH, Kerwin RW: Antidepressants enhance glucocorticoid receptor function in vitro by modulating the membrane steroid transporters. Br J Pharmacol 200I, I34(6): I335-1343.

19. Mathieu M, Gougat C, Jaffuel D, Danielsen M, Godard P, Bousquet J, Demoly $P$ : The glucocorticoid receptor gene as a candidate for gene therapy in asthma. Gene Ther 1999, 6:245-252.

20. Tamura T, Morinobu S, Okamoto Y, Kagaya A, Yamawaki S: The effects of antidepressant drug treatments on activator protein-I binding activity in the rat brain. Prog Neuropsychopharmacol Biol Psychiatry 2002, 26(2):375-38I.

21. Okamoto H, Shino Y, Hashimoto K, Kumakiri C, Shimizu E, Shirasawa $\mathrm{H}$, lyo M: Dynamic changes in AP-I transcription factor DNA binding activity in rat brain following administration of antidepressant amitriptyline and brain-derived neurotrophic factor. Neuropharmacology 2003, 45(2):25I-259.

22. Post A, Crochemore C, Uhr M, Holsboer F, Behl C: Differential induction of NF-kappaB activity and neural cell death by antidepressants in vitro. Eur J Neurosci 2000, I 2( I 2):433 I-4337.

23. Donovan CE, Mark DA, He HZ, Liou HC, Kobzik L, Wang Y, De Sanctis GT, Perkins DL, Finn PW: NF-kappa B/Rel transcription factors: c-Rel promotes airway hyperresponsiveness and allergic pulmonary inflammation. J Immunol 1999, 163(12):6827-6833.

24. Nguyen C, Teo JL, Matsuda A, Eguchi M, Chi EY, Henderson W Jr, Kahn M: Chemogenomic identification of Ref-I/AP-I as a therapeutic target for asthma. Proc Natl Acad Sci USA 2003, 100(3): I I69-1 I73.

25. Bohrer H, Qiu F, Zimmermann T, Zhang Y, Jllmer T, Mannel D, Bottiger BW, Stern DM, Waldherr R, Saeger HD, et al:: Role of NF-kappaB in the mortality of sepsis. J Clin Invest 1997, I 00(5):972-985.

26. Glotzbach RK, Preskorn SH: Brain concentrations of tricyclic antidepressants:single-dose kinetics and relationship to plasma concentrations in chronically dosed rats. Psychopharmacology (Berl) 1982, 78(I):25-27.

27. Orsulak PJ, Kenney JT, Debus JR, Crowley G, Wittman PD: Determination of the antidepressant fluoxetine and its metabolite norfluoxetine in serum by reversedphase HPLC with ultraviolet detection. Clin Chem I 988, 34(9): I875-1878.

28. Peer D, Dekel Y, Melikhov D, Margalit R: Fluoxetine inhibits multidrug resistance extrusion pumps and enhances responses to chemotherapy in syngeneic and in human xenograft mouse tumor models. Cancer Res 2004, 64(20):7562-7569.

29. Kavallaris M, Kuo D, Burkhart C, Regl D, Norris M, Haber M, Horwitz $S$ : Taxolresistant epithelial ovarian tumors are associated with altered expression of specific beta-tubulin isotypes. J Clin Invest 1997, 100: 1282-1293.

30. Wang $\mathrm{H}$, Yang $\mathrm{H}$, Tracey KJ: Extracellular role of HMGB I in inflammation and sepsis. J Intern Med 2004, 255(3):320-33I.

31. Sacerdote P, Bianchi M, Panerai AE: Chlorimipramine and nortriptyline but not fluoxetine and fluvoxamine inhibit human polymorphonuclear cell chemotaxis in vitro. Gen Pharmacol I994, 25(3):409-4I 2.

32. Les ventes d'antidépresseurs entre 1980 et $200 \mathrm{I}$ [http:// www.sante.gouv.fr/drees/etude-resultat/er-pdf/er285.pdf]

33. Kozora E, Ellison MC, West S: Depression, fatigue, and pain in systemic lupus erythematosus (SLE): Relationship to the American College of Rheumatology SLE neuropsychological battery. Arthritis Care \& Research 2006, 55(4):628-635. 
34. Lechin F, van der Dijs B, Orozco B, Jara H, Rada I, Lechin ME, Lechin $A E$ : The serotonin uptake-enhancing drug tianeptine suppresses asthmatic symptoms in children: a double-blind, crossover, placebo-controlled study. J Clin Pharmacol 1998, 38(10):918-925.

35. Brown ES, Vigil L, Khan DA, Liggin JD, Carmody TJ, Rush AJ: A randomized trial of citalopram versus placebo in outpatients with asthma and major depressive disorder: a proof of concept study. Biol Psychiatry 2005, 58(I I):865-870.

Publish with Bio Med Central and every scientist can read your work free of charge

"BioMed Central will be the most significant development for disseminating the results of biomedical research in our lifetime. " Sir Paul Nurse, Cancer Research UK

Your research papers will be:

- available free of charge to the entire biomedical community

- peer reviewed and published immediately upon acceptance

- cited in PubMed and archived on PubMed Central

- yours - you keep the copyright

Submit your manuscript here:

http://www.biomedcentral.com/info/publishing_adv.asp
BioMedcentral 